\title{
CONSTRUCTING COMPLIMENT IN ENGLISH AND BAHASA INDONESIA : A COMPARATIVE STUDY
}

\section{MENYUSUN SANJUNGAN DALAM BAHASA INGGRIS DAN BAHASA INDONESIA: SEBUAH STUDI PERBANDINGAN}

\author{
Saiful Akhyar, S.Pd. \\ SMAN I Pemenang \\ paullombok@yahoo.com
}

Diterima: 20 November 2015, direvisi: 17 Desember 2015, disetujui: 22 Desember 2015

\begin{abstract}
Compliment defined as a form of appreciation, entertainment, manifesting of satisfaction, and the way of encouragement to increase the learning motivation. It identifies that the form of compliment take some varieties of patterns. In Bahasa Indonesia, using metaphor seems to be one of the alternatives forms of composing compliment. It is also used by any different profession of humankind, from personal to interpersonal relationship, from ordinary people to the top politicians, in the formal and informal institution. In teaching and learning activity, teacher proposes compliment as the essential topic that must be acquired by the students. The acquisition of compliment can be taught by numerous strategies and techniques. It depends on the situation and school environment. The knowledge of linguistic expressions and sociolinguistics rules of the relevance topic should be put as the top consideration.
\end{abstract}

Key words : compliment as service, compliment as utterances, entertainment.

\begin{abstract}
Abstrak
Sanjungan dimaknai sebagai sebuah bentuk apresiasi, hiburan, perwujudan kepuasan, dan cara untuk meningkatkan motivasi belajar. Studi ini menjelaskan bahwa bentuk sanjungan memiliki beberapa pola. Dalam bahasa Indonesia, penggunaan metafora merupakan salah satu bentuk dari sanjungan. Bentuk ini digunakan juga oleh berbagai profesi manusia, baik dalam hubungan personal maupun interpersonal, dari rakyat biasa sampai ke politisi tingkat tinggi, dalam institusi formal dan informal. Dalam kegiatan belajar dan pengajaran, guru memakai sanjungan sebagai sebua materi yang harus dikuasai oleh siswa. Pemerolehan sanjungan dapat diajarkan dengan berbagai teknik dan strategi, tergantung dari situasi dan kondisi. Pengetahuan tentang ungkapan linguistik dan aturan sosiolinguistik terhadap topik yang relevan merupakan hal yang paling penting untuk dipertimbangkan.
\end{abstract}

Kata kunci: Sanjungan sebagai sebuah layanan, sanjungan sebagai ungkapan, hiburan.

\section{Introduction}

As social creatures, human beings must interact with others. When they are making interpersonal relationship, they sometimes identify anything of their colleagues, either good things or bad ones. When you find something good, it emerges a sense to admire her/him. The willingness to praise is normal for human, and is also as form of creating warm situation in making interrelation. It is one of the ways to please friends or someone else. By complimenting others, it shows that we are appreciating them. It can grow their self confidence, and increase the motivation. In the term of teaching and learning process, complimenting can be used as a way of encouragement to raise the learning spirit of the students. It is persuaded to the teachers using flattery as strategy when handling the learning process to avoid the 
loss of enthusiasm. Regier (2007) described the aim to flatter is the way to calm the others down, make them more relaxing when they are facing any problems of life, and in conducting interpersonal relationship. It can use to raise the happiness from the deep sorrow of others, and having pleasure instead of lamenting the suffering. It is also referred to a kind of entertainment from the lower position of staff to the higher level to get personal advantages

It has numerous goals of the people to flatter anyone else, but it is clearly described that it is a form of honor from others. Even though, it is frequently use for negative intention.

Other scholars explain varieties of definitions for compliment. Holmes (1988:446, 1995:117)) defined compliments as,

"speech act which explicitly or implicitly attributes

credit to someone other than the speaker, usually the person addressed, for some 'good' (possession, characteristic, skill, etc.) which is positively valued by the speaker and the hearer".

While Manes and Wolfson (1981:116) stated more comprehensive definition about compliment, they said that compliment is," Expressions of positive evaluation". It means that any forms of expressions to appreciate others can be regarded as compliment.

This writing focuses on the usage of compliments in daily life of English and Indonesian community. It tries to emerge the forms of the compliments in two different segments and interests of people. How to formulate compliments in the term of teaching and learning process in the education institutions.

\section{Literature Review}

Studying compliment seems quite interesting. It presents variety of attracting views in the field of applying and the form of it. It is emerged a number of responses in the speakers and hearers. Some interpretations adduced by researchers based on the findings. Although the concentration of study is not as many as other topics, but it can be said that it is quite interesting to explore more about it.

Knap, Hopper and Bell (1984) arranged a research by involving 15 interviewers of undergraduate and graduate students. The interviewees were from the parents, relatives of the students who attending Midwestern University, and workers at Social Security Administration Headquarters in Washington DC. The respondents/interviewees involved 30 male and 35 female, age ranged between 12 to 80 years old, and they live in New York State. The interview designed to obtain any information about the content and form and replies of compliment, the frequency used of it. The questions were also about who gave and received the compliment, and how they delivered it. The study proposed 116 types of compliments and replies.

The findings were about the content categories of compliment. They are performance, attire, appearance, personality/whole person, possessions, and helping/service. The most frequency occurred are that people give compliments related to their performance and attire. The characteristic of the compliment form is dominantly direct form. The research also found that most the receiver response the compliment with acceptance, and acceptance with amendment. The highest frequency of the receiver's reply is ritual acceptance and 
pleased acceptance. It described also that female of age range 30 dominantly received the compliment.

It seems that the study covered almost all components of compliment, but, it actually just focused on the compliment in the form of utterances. It did not cover it comprehensively. As a matter of fact, compliment does not merely about utterances, but compliment is related with entertainment as well, and it deals with how to treat someone else. And it should be about service. Service as compliment naturally will lead into the things you may give and present to your relatives and colleagues. And the research actually did not mention specifically about it.

Another research of compliment was done by Jucker (2009). This study took three different kinds of methods, named Armchair Method, Field Method, and Laboratory Method. In Armchair Method the researcher arranged an interview involving native and nonnative speakers. The researcher tried to find out the speakers intuition about the language and language use. It explored of the speaker's attitude toward compliment and its response. Field Method focused on collecting data from written and spoken sources which were produced in communication forms. It is like emails, letters, short messages and other personal communication form. The researcher took note all compliments occurred in the media. The Laboratory Method was hold by stimulating informants to produce such utterances related to the topic required. The result would be on the cooperation of the respondents. This research aimed at finding the nature of the compliment. It is sincere, empty or just an ironic. The other goal of the study also tried to find the syntactic pattern of the compliment, who use it, it addressed to whom and in what situation. The object of compliment was included in the research.

The result of the study found that the top percentage of compliment intended to women rather than men. It occurred 51.2 percent among the women. The object of the compliment mostly refers to the appearance of the addressees, either female to female or male to female compliment. The receiver responses are generally agreed with the compliment. They regarded as an appreciation, and accepted positively. The writer found that almost all the respondents produced the same syntactic pattern.

Indeed, the researcher as his claimed would like to explore this topic more comprehensively. It is shown by the applying of three different methods. But, it is still questionable to the writer about the receiver's perception, especially about the attitude toward compliment. The writer does not elaborate how such a compliment regarded positively. It should be cleared that in which situation and context it is uttered. In which relationship is the compliment given. When a staff complimenting their boss frequently, it needs to question, is it sincere? Or they have a hidden agenda. The researcher must add other category of compliments by proposing the relationship category.

\section{Research Method}

In relevance to the purpose of the study, qualitative method was used in analyzing data gathered. On the basis of corpus, English language data were gained from Wolfson's Paper (1981) "Compliments in Cross-Cultural Perspectves"

Meanwhile, Indonesian language data were taken from Mutmainnah and 
Patriana (2005) "Respon Pujian Dalam

Bahasa Indonesia oleh Dwibahasawan Indonesia-Inggris". Participant observer is proposed to be the data source of this research as well.

Sociolingustic approach was used in terms of relationship between sociolinguistic competence and rule of speaking. The linguistic aspects and the diversity of social behavior of the native speakers influence the compliment patterns and the structure of the compliment.

Based on the approach, data gathered was analyzed for finding the relevance of compliment construction, the speaking rule, and the acquisition strategies of the target language.

\section{Discussion}

\subsection{Compliments as a service versus compliments as a praise}

From the description of the experts, compliments may refer to two different forms. They are compliment as services and as utterance or expressions. The first type normally finds in business or hospitality and in particular service industry. It deals with satisfactory service. When having meal in a restaurant, giving tips to food server is recommended as manifestation of the effective amelioration from the customers. Tipping behavior can be as the extra incomes of the employee. It is also used by the company as the measurement of the customer's satisfaction (Seiter \& Weger, 2010).. Entertainment, which regarded as another form of compliment, is related to the treatment for one's business partners. It is to be common habit to welcome colleagues and relations in ultimate treatment. To keep good relationship in business affairs, it is frequently found that business people greet their partners by giving some facilities. It is intended to maintain the business relationship running smoothly. Brown \& Levinson (1987) described that one of the way to show the politeness strategy in human relationship is by giving compliments. This sort of entertainment may refer to be a form of compliments in the term of business field.

Another form of compliment is possibly related to the utterance or expressions, herewith called compliments as praise. This kind of compliments is frequently appeared in spoken and written communication. Convergence is often taken by the people when maintain the warm relation to others. It is a great appreciation when someone got flattery. In keeping conducive interrelation, that attitudes can be used as the proposition of feeling solidarity.

Your lovely intimated friend should be felt pleasure when you give a praise to her/him. Have you ever imagined that your close friend says, "you are the best for me!", or your wife says, "you make my life being worthy!". Those utterances or expressions are of course really valuable for you. When you are happy to get the praise, it means the aims of compliments are successful.

If you are teachers, expression like, "you are brilliant!", or, "very good, you are smart student!", must be very familiar with you. It can build the self confidence for the students. It may increase motivation, and encourage them to be better. It seems so simple, but it can change the student's life. It influences the learning mindset of the way they perceive the learning activity. Psychologically, they feel appreciated by the teacher, and will create positive attitudes into the learning materials, process, and the teacher himself. 


\subsection{Compliments in English}

All languages inherently have variety forms of compliments. It is commonly found in such situation and context of conversation. English as the most favorable language even put compliment as a significant component that should be occupied by the learners. It is frequently heard the speakers of English either the native speakers or non native speaker utter such compliment in their daily communication. English speakers use the compliments in any chance, in casual or very formal situation, by ordinary or top class of person, in personal or public affairs, in business or political issues. Sometimes it impressed extremely over, and can make misunderstanding among the speakers. It happened when Jimmy Carter went to France in the term of his position as The President of America. Giving compliments for any possession, service, achievement, and attracting performances are being the habit for American. It frequently creates misinterpretation for the non-native speakers. The French people felt that it is effusive and considered having hidden agendas (Wolfson, 1989).

The expression like,"How good to meet you! I've heard so much about you". (Regier, 2007). It is a friendship form of compliment in English. It is used when seeing someone at the first time. When Nixon uttered rudeness statement, Kissinger answered by saying,"Yes Mr. President, your analysis is absolutely correct and certainly very profound". (Regier, 2007). It shows that English people use compliment even though they accepted outrageous statements. The samplings compliments above pointed out that it is applied by any classes of people, and inter contexts of topic of such conversation.

Wolfson (1981) proposed some syntactic patterns of compliment which are generally used in English :

Pattern 1:

NP ${ }^{[\text {is }] \text { (really) ADJ }}$

(e.g. You look good, This chicken is great, Your pin looks nice like that)

Pattern 2 :

[ like ]

I (really) NP

[ love ]

(e.g. I like your shirt, I love your blouse)

Pattern 3 :

PRO is (really) (a ) ADJ NP

(e.g. That's a good system, That's a very nice briefcase ).

The other patterns adduced by Manes and Wolfson (1981), they are :

Pattern 1: You V ( a ) (really) ADJ NP

(e.g. You did a good job, You speak very good English)

Pattern 2: You V ( NP) (really) ADV

(e.g. You really handled that situation well ). 
Pattern 3: You have (a ) (really) ADJ NP

(e.g. You have such beautiful hair ).

Pattern 4: What (a ) ADJ NP!

(e.g. What a lovely baby you have !)

Pattern 5: ADJ NP!

(e.g. Nice game!)

Pattern 6: Isn't NP ADJ!

( e.g. Isn't your ring beautiful! )

These patterns of composing compliments are frequently used by the native and non-native speakers of English. It seems that these are really familiar in interpersonal communication in the English community, either as the first or the second language.

\subsection{Compliments in Indonesian language}

Complimenting in the Indonesian culture is definitely welcome and happened in any situation of contexts. It is done for many different intentions of the speakers. However, it is deliberately made to propose positives interrelation in everyday life. Complimenting behavior is absolutely present in any setting of conversation. It is occured in formal and informal communication and institutions. Flattering others can grow mutual understanding and continuity of relationship among the people of such a society. Intimately and sharing of happiness, giving honor to others are $\mathrm{A}$ : being the basic principle of the Indonesian philosophy of life. It may descend from the doctrine of their religion and or the local tradition.

In constructing the complimenting, it should be differed from one to other contexts. And it is possibly varied for different ethnic groups. Compliment is also regarded as a form of politeness in any social class. Thus, meaning of complimenting can be used as stereotypical of the social groups. The goal of complimenting is depending on personal interests, social background, and profession of the speakers. (Terkourafi's, 2001, 2007). Hence, it is clearly found in Indonesian daily life that compliment is integrated in the behavior and utterances emerged in the conversation and the treatments of the speakers.

The expression like, "Bagus!, Hebat! Pekerjaanmu sangat memuaskan!, Pertahankan prestasimu $y a ! "$, are frequently used by teachers when the teaching and learning in progress. These simple expressions can be meaningful and can drive the motivation and learning spirit of the students.

Let's take a look at this dialogue, taken from Mukminatien and Patriana (2005). (Percakapan sesama dosen mengomentari jilbab baru)

A : Cakep jilbanya

B : (Tersenyum) terima kasih. Aku suka yang dominan hitam gini ini.

Ya. Ibu pantas aja pakai hitam. Kalau aku ya... (ujaran tidak dilanjutkan, sambil pergi keluar ruangan)

The above dialogue points out that in Bahasa Indonesia compliments can occur as the opening of such a conversation, and it is probably followed by other flatteries despite in a narrow space.

Speaker of Bahasa Indonesia is allowed to use metaphor to praise others. It commonly finds in the old literature that a number of novelists exploited metaphor in their writings. It is one of the ways to complimenting their adorable 
person or things. In the romance of young people, the expression like," Kamu bagaikan bulan purnama di malam hari”, Kamu adalah malaikat kecilku". These personifications tend to be used in complimenting, and it is accepted when making social interrelation.

\subsection{Teaching compliments in SLA Class}

In teaching second language class, compliment seems to be crucial material that should be acquired by the students. The acquisition should be met the standard of the target language, either in the form of its linguistic or speaking rules. It must avoid Indonesian construction and principles when forming the compliments. It should not impress effusive utterances by the addressees.

In response to such cases, teachers are supposed to design relevant teaching techniques. In this respect, teacher provides incomplete conversation of relevance topic, motivating students to give response to it. It is like as follow:

Teacher: What are you going to say when you know your friend got a highest score?

Student :

The answer is probably, "You are great!", or provides any other relevant answers. Other optional is performance method. In this respect, teacher must select a short conversation of relevance topic, and ask the students to perform in front of the class.

It needs considering the strategy of Graham and Brown (1996), they recommended to acculturate the students into a community of the target language, this approach will enable the students of L2 to integrate with native speakers, and they can communicate the target language by proposing some questions about the topic, and that will be an effective strategy for the teaching and learning process.

It of course needs more expenses, but it can arrange for a periode of time. It should not visit the country of the target language. Instead, they may go to a tourist resort. Naturally, they will attain the proper linguistic expressions and sociolinguistic rules of the target language from the authentic sources.

\section{Conclusion}

Compliment can be decomposed into compliment as a service and as an entertainment. It is the essential part in both English and Indonesian language. It occurs in variety of situations and contexts of communication. It used by the speakers of all social class. The speakers apply the compliment for numerous intentions and aims. It can take for entertainment, appreciating, amelioration, and or satisfactory measurement.

The speakers of English and Indonesian language form compliment in many different patterns. They are mostly using noun, adjective, intensifiers, and pronoun/to be in constructing flattery. The using of such a language style, as metaphor is frequently applicable, and it is often find in old literature.

In the teaching and learning process, this topic can be taught by some optional techniques and strategy. It depends on the needs, situations and geographical potential of the school environment. Expense also determines the consideration of learning activity. 


\section{References}

Graham, Ray C. and Brown, Cheryl (1996). "The Effects of Acculturation on Second Language Proficiency in a Community with a Two-Way Bilingual Program". The Bilingual Research Journal. Spring 1996. Vol. 20. No. 2. Brigham Young University

Jaworski, Adam (1995). "This is not An Empty Compliment!" Polish Compliments and The Expression of Solidarity. International Journal of applied linguistics, vol. 5 NO. 1, 1995.

Jucker, H. Andreas, Schneider, Gerold, Taavitsaenen, Irma, and Breustedt, Barb (2008). Speech Acts in The History of English, ed. Andreas $\mathrm{H}$. Jucker and Irma Taavitsaenen. John Benjamins Publishing Company. Amsterdam/Philadelphia.

Jucker, Andreas H. (2009). Speech Act Research between Armchair, Field and Laboratory. The Case of Compliments. Journal of Pragmatics 41 (2009). 1611-1635.

Jucker,H.Andreas, Schneider, Gerold, Taavitsaenen, Irma, and Breustedt, Barb (2008). Fishing for Compliments, Precision and Recall in Corpus-Linguistic Compliment Research. In Speech Acts in The History of English, ed. Andreas H. Jucker and Irma Taavitsaenen. John Benjamins Publishing Company. Amsterdam/Philadelphia.
Knapp, Mark L, Hopper, Robert, and Bell, Robert A. (1984). "Compliments : A Descriptive Taxonomy". Journal of Communication. Autumn 1984.

Mukminatien, Nur and Patriana, Wisnu Andhina (2005). "Respon Pujian dalam Bahasa Indonesia oleh Dwibahasawan Indonesia-Inggris". Bahasa dan Seni. Tahun 33 Nomor 2, Agustus 2005

Mills, Sara and Kádár, Dániel Z. (2011). Politeness and The Culture. In Politeness in East Asia, ed. Sara Mills and Dániel Z. Kádár. Cambridge University Press. New York

Regier, Willis Goth (2007). In Praise of Flattery. University of Nebraska Press: Lincoln and London.

Seiter, John S. \& Weger, Harry Jr. (2010) "The Effect of Generalized Compliments, Sex of Server, and Size of Dining Party on Tipping Behavior in Restaurants". Journal of Applied social psychology 2010. Journal compilation by Wiley Periodicals, Inc.

Wolfson, Nessa (1989). Perspectives, Sociolinguistics and TESOL. Newbury House Publishers. New York.

Wolfson, Nessa (1981). "Compliments in Cross-Cultural Perspectives”. TESOL QUARTERLY. Vol. 15, No. 2 